\title{
A mística cristã e o diálogo inter-religioso em Thomas Merton e em Raimon Panikkar Para uma maturidade cristã e uma mística inter-religiosa
}

\author{
Orientadora: Maria Clara Lucchetti Bingemer \\ Doutoranda: Francilaide de Queiroz Ronsi \\ Área de Concentração: Teologia Sistemático-Pastoral \\ Linha de Pesquisa: Religião e Modernidade
}

O reconhecimento da realidade religiosa, ricamente plural em que nos encontramos, nos convida a buscar formas para que seja possibilitado o convívio harmonioso em nossa sociedade. Para o Cristianismo, em especial, lhe é proporcionado a busca por uma intensa experiência nas mais profundas raízes de sua origem religiosa e a compreensão do significado dessa pluralidade religiosa no projeto salvífico de Deus e sua relação com o mistério de Jesus Cristo. Por isso, acreditamos que, para o diálogo fecundo e acolhedor com as demais religiões, é de extrema importância a contribuição de um caminho espiritual enraizado na experiência de união com Deus, como possibilidade para que não se viva uma religiosidade muito epidérmica, recuperando a dimensão da experiência íntima do mistério de Deus e da experiência da unidade com ela. As experiências vividas por Thomas Merton e Raimon Panikkar, radicadas no cristianismo, de profunda intimidade com Deus, nos apresentam um caminho para um diálogo inter-religioso realizado a partir de uma madura experiência religiosa. A experiência de Thomas Merton é profundamente inseparável do amor a Deus e à humanidade, em um seguimento aos ensinamentos de Jesus Cristo na dedicação ao seu ministério de sacerdote, monge e eremita, ricamente fortalecida pelo amor aos humanos. Em Raimon Panikkar, encontramos uma pessoa marcada por quatro identidades religiosas, sem que lhe fosse negada sua primeira origem, o cristianismo, caracterizada por uma profunda experiência de encontro com Deus. Para Raimon Panikkar este é o kairós do milênio que recém se abriu para todas as religiões e continuar com pequenas reformas não tem sentido. É necessária uma grande transformação, porém profunda, uma metanóia! Segundo Thomas Merton e Raimon Panikkar o diálogo entre as experiências religiosas não se resume a 
uma conversão vazia, mas que os interlocutores tenham de fato, penetrado com a máxima seriedade em sua própria tradição, assumindo a dimensão espiritual como o nível mais fecundo para a abertura e compreensão no diálogo inter-religioso. A partir destas experiências, sugerimos que o diálogo inter-religioso ultrapasse as fronteiras que separam as religiões em uma sincera e fecunda acolhida das mais diversas tradições, a partir de uma madura experiência religiosa. Através das contribuições de Juan Martin Velasco e de Andrés Torres Queiruga, confirma-se a importância que têm a dimensão espiritual e a experiência interior que possuem todas as religiões diante da autêntica necessidade do diálogo inter-religioso. Em todas as religiões existe a experiência mística unicamente graças ao convite de Deus, que deseja tornar-se conhecido e, acolhendo esta Presença, o ser humano tem a possibilidade de atingir sua autêntica realização. Sem fazer oposição à singularidade cristã na interpretação positiva das outras religiões e do pluralismo religioso, acreditamos que a maturidade da experiência religiosa do cristão contribui para aproximá-lo da realidade de ser imagem de Deus, que se dá na experiência mais profunda do ser religioso a partir de uma íntima relação com Deus.

Palavras-chave: Pluralismo; diálogo inter-religioso; mística. 